visiting Victoria Falls in Zimbabwe. The geographic odyssey of his career spoke for his desire to touch as much of the Earth as he could and understand the environments that comprise it. For Frank Dale the world was much more than a place to do business or engage in diplomacy; it was a Biosphere of many special parts in need of protection and enhancement.

That is what motivated him a few autumns ago to take time from an overfilled schedule to come to the mountains of Switzerland*, sit patiently through scholarly deliberations, and advise an ivory-tower group of environmentalists on how to communicate their findings and philosophies to the rest of the world and meanwhile develop resources for future endeavours. In a world of CEO-level commitments, pro bono work for the Council was an important priority to Frank Dale.

I first met Frank at a dinner party hosted by the editor of a leading environmental journal. This was well before the days when concepts such as green business and industry-environment community cooperation were well-accepted ones; and I remember how my initial reaction was to wonder why someone from the business world would be at such a function, and, for that matter, what he would have to contribute - which suspicion was probably mutual.

* and later spend a near-week in Budapest, Hungary, participating enthusiastically in our Fourth International Conference on Environmental Future - see the book of proceedings, entitled Surviving With The Biosphere, published recently by Edinburgh University Press. - Ed.
By the end of the evening, however, any doubts had long dissolved, and I had learned some real specifics on how top management views environmental issues, and what bottom-line considerations are all about. More generally, that initial meeting provided much food for thought on how to bridge the chasms between different environmental interests, and optimize the resources of the business community for progressive environmental policymaking. Here, at that memorable dinner-table, was a very special type of resource.

Today, as we move into an era where managers and decision-makers of all kinds will be increasingly oriented towards environmental issues, the need for developing this resource-base to the fullest is clear. The challenges of bringing the skills and perspectives of upper-level management into the environmental mainstream, and developing ongoing forums for substantive information exchange between these managers and environmental specialists, are considerable. Not all CEOs are as willing an audience as was Frank Dale. He was a powerful role model for the kinds of leaders that will be needed to turn the ' 90 s' environmental goals into viable realities of the next century. He will be very much missed; hopefully, though, the example which he set will continue to shine.

ARTHUR H. PURCELL, President
Resource Policy Institute
1145 Selby Avenue, Nr II
Los Angeles
California 90024
USA.

Arthur H. Purcell, President Resource Policy Institute

Los Angeles

USA.

\title{
Francis L. Dale - Further Appreciation
}

$\mathrm{W}$ hereas we had, ever since receiving the shocking news of his untimely death, intended to write a full obituary of Frank Dale, the above 'Personal Reflection', contributed by a mutual friend, already portrays him so well that we merely add here our endorsing appreciation and a characteristic photograph of Frank with his delightful wife, née Kathleen Hamlyn Watkins, to whom our fondest respects and sad condolences are always due.

From our earliest association when Frank was United States Ambassador and Permanent Representative to the European Office of the United Nations and other International Organizations in Geneva, Switzerland, in the mid-1970s, we felt that he exemplified to an extraordinary extent one of The Biosphere's greatest needs, namely of widely-versed, experienced, and effective leaders who would apprise decision-makers of environmental dangers. Concerning such dangers Frank was invariably attentive and, when convinced, most effectively outspoken. That continues to be - indeed increasingly with more and more people overcrowding Planet Earth - one of our most crying needs, namely the 'putting over' of urgencies and imperatives to the quarters that will engender necessary action. Let us all hope with our above correspondent, and indeed quite ardently, that Frank Dale's example 'will continue to shine' and so help towards the ultimate goal of biospheric stability.

NichOLAS POLUNIN

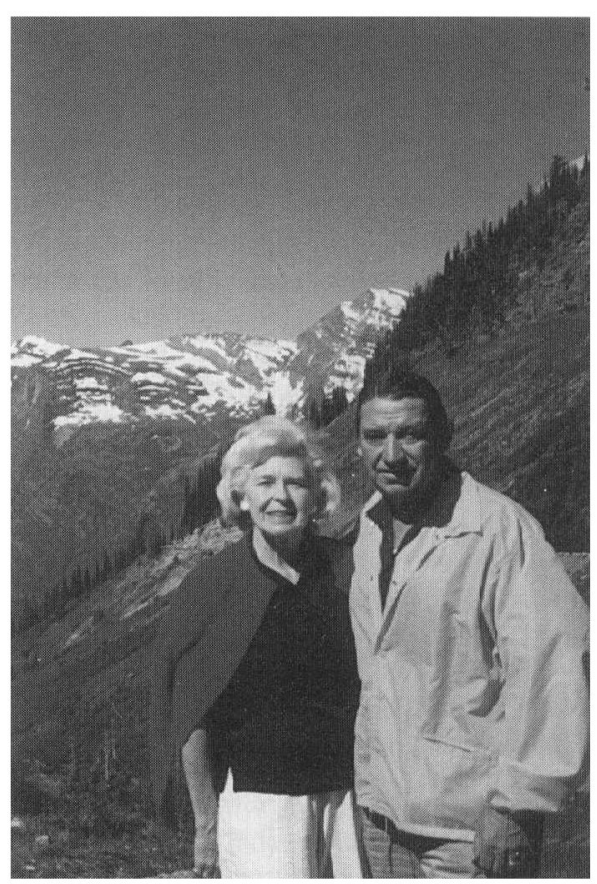

FIG. 1. Kay and Frank Dale in Glacier National Park, Montana, in 1989. 